\title{
RESEARCH
}

\section{Correlation Between Levels of Interleukin-6 in Peritoneal Fluid and Degree of Pain, Adhesion, Endometriosis Fertility Index Score in Endometriosis}

\author{
Angga Trifianda Prima1, Dedy Hendry ${ }^{2}$, Hafni Bachtiar ${ }^{3}$ \\ Affiliation author:1. Obstetricsand Gynecology, Faculty of Medicine,Andalas University, Dr. M. \\ Djamil Central General Hospital Padang, West Sumatera, Indonesia; 2. Sub Division of Reproductive \\ Endocrinology, Obstetrics and Gynecology Department, Faculty of Medicine, Andalas University, Dr. \\ M. Djamil Central General Hospital Padang, West Sumatera, Indonesia; 3. Public Health \\ Department, Faculty of Medicine,Andalas University Padang, West Sumatera, Indonesia \\ Correspondence to:Angga Trifianda Prima, email: anggaboujank@gmail.com, Hp:08126742081
}

\begin{abstract}
Introduction : Endometriosis is a benign gynecological disorder characterized by the presence of endometrial tissue and stroma outside the uterine cavity. Several theories have been proposed to explain the occurrence of endometriosis, one of which is the theory of inflammation. Endometriosis lesions can produce inflammatory cytokines, resulting in their increased levels in the peritoneal fluid. This process causes disruption in pelvic anatomy, ovarian function, prostaglandin production and growth factor production that causes pain, adhesions and infertility. Interleukin-6 (IL-6) is an important and potential inflammatory cytokine in assisting the diagnosis of endometriosis, act as activating macrophages that can stimulate endometrial cell proliferation and modulate the secretion of other cytokines such as $I L-10, I L-13$ and TNF- $\alpha$ which augments the inflammatory process. High levels of IL-6 in the peritoneum are related to advanced endometriosis associated with pain, severe pelvic adhesions and embryotoxic effects leading to infertility. The effect of IL-6, both local and systemic, on the growth of endometriosis lesions and its associated symptoms is great that this cytokine is considered an important marker.
\end{abstract}

Objective : To determine the relationship between local inflammatory factors (IL-6 in peritoneal fluid) with the degree of pain, adhesions and the correlation with the Endometriosis Fertility Index (EFI) score in endometriosis patients.

Material and methods: This is a quantitative analytic research with a cross sectional study design which was conducted on 22 patients with endometriosis. Prior to the laparoscopy, historical factor (EFI score) was recorded and an assessment of the pain scale was performed by filling out a questionnaire. Intraoperatively, the peritoneal fluid was obtained, then examination was carried out using the RayBio Human IL-6 ELISA Kit. During the laparoscopy procedure, the degree of adhesion of the pelvic organs was assessed by looking at the shape and how the adhesions can be separated. Surgical factor (EFI score) was assessed intraoperatively to obtain data for the least function score, AFS endometriosis score and AFS total score. Statistical analysis was performed using paired t test and correlation test.

Results : The mean age of the respondents was $34.86 \pm 6.11$ years, $81.8 \%$ were nulliparous, $100 \%$ were married, $100 \%$ experienced both primary and secondary infertility and $81.8 \%$ had no prior pregnancy history. In the study, it was found that IL-6 levels of peritoneal fluid were higher in 


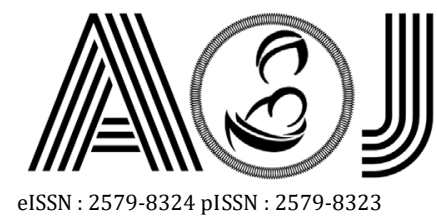

eISSN : 2579-8324 pISSN : 2579-8323
ANDALAS OBSTETRICS AND GYNECOLOGY JOURNAL

Address for Correspondence:

Editorial RoomAndalas Obstetrics and Gynecology Journal, $3^{\text {rd }}$ floorof KSM of Obstetrics and Gynecology, RSUP DR. M. Djamil Padang, Jl. Perintis Kemerdekaan Padang, Sumatera Barat 25127

Website:

http://jurnalobgin.fk.unand.ac.id/index.php/JOE

patients with the degree of severe pain $(P<0.05)$ compared to moderate with the results of $32.58 \pm$ $7.31 \mathrm{pg} / \mathrm{ml}$ and $25.39 \pm 2.70 \mathrm{pg} / \mathrm{ml}$. IL-6 levels were found to be higher in grade three adhesions than grade two $(P<0.05)$ with results of $32.78 \pm 6.65 \mathrm{pg} / \mathrm{ml}$ and $23.86 \pm 2.18 \mathrm{pg} / \mathrm{ml}$. The mean peritoneal fluid IL-6 levels were $30.75 \pm 7.01 \mathrm{pg} / \mathrm{ml}$ and the mean EFI score was $4.09 \pm 2.09$. The correlation of IL-6 levels in peritoneal fluid with EFI score showed a value of $r=-0.448$ which had moderate strength and a negative pattern, indicating that the higher the IL-6 level of peritoneal fluid, the lower the EFI score $(P<0.05)$.

Conclusion : There is a relationship between IL-6 levels of peritoneal fluid in endometriosis with the degree of pain and the degree of adhesion $(P<0.05)$. There was a negative correlation between IL-6 levels of peritoneal fluid with EFI score $(P<0.05)$.

Keywords: Endometriosis, Interleukin-6, Degree of Pain, Degree of Adhesion, Endometriosis Fertility Index Score

\section{BACKGROUNDS}

Endometriosis is a benign gynecological disorder characterized by the presence of endometrial tissue and stroma outside the uterine cavity. ${ }^{1,2}$ This chronic disease affects women's health and quality of life. ${ }^{3}$ Dysmenorrhea, chronic non-menstrual pelvic pain, dyspareunia, dysuria, dyschezia and infertility are the main symptoms of endometriosis. $4,5,6$ The prevalence of endometriosis in women with reproductive age is reported to be $20-50 \%$, especially those aged 15-49 years. ${ }^{7,8}$ The incidence of endometriosis in women with infertility was found to be $9-50 \% .{ }^{9,10}$ Caterina Morassuto et al. reported the incidence of endometriosis in Italy during 2011-2013 were 979 (69\%) from 1,415 women, especially aged $15-50$ years. ${ }^{8}$ Research Ina Rahayu et al in Dr. Soetomo Hospital Surabaya found 57 cases of endometriosis were found at the age of $20-35$ years $(39.1 \%)$ and $64.9 \%$ experienced dysmenorrhea from April 2012 to March 2013. ${ }^{11}$ The incidence of endometriosis in Dr. M. Djamil Hospital Padang from January 2017 to October 2018 found that there were 160 cases with most cases are found to be from the age group of 36-45 years old. ${ }^{12}$

Several theories tried to explain the pathophysiology behind endometriosis such as retrograde menstruation and implantation theory, lymphatic and vascular embolism, celomic, hormonal metaplasia, immunological and inflammatory dysfunction and genetic predisposition. ${ }^{9}$ The most adapted theory is the retrograde menstruation theory proposed by Sampson in $1927 .{ }^{11}$ Nowadays, inflammation theory is currently the most developed. ${ }^{13}$ Unlike the normal endometrium, endometriosis cells secrete inflammatory cytokines, increasing the levels in the peritoneal fluid. Increased inflammatory and angiogenic activity of the peritoneum and peritoneal fluid coupled with poor clearance of endometrial cells from the pelvic cavity contribute to the development of endometriosis. Meng-Hsing Wu et al. concluded that inflammatory factors influence the incidence of endometriosis and can interact both locally and systemically to cause symptoms. ${ }^{13,14}$ 


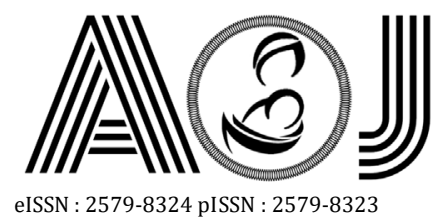

eISSN : 2579-8324 pISSN : 2579-8323
ANDALAS OBSTETRICS AND GYNECOLOGY JOURNAL

Address for Correspondence:

Editorial RoomAndalas Obstetrics and Gynecology Journal, $3^{\text {rd }}$ floorof KSM of Obstetrics and Gynecology, RSUP DR. M. Djamil Padang, Jl. Perintis Kemerdekaan Padang, Sumatera Barat 25127

Website:

http://jurnalobgin.fk.unand.ac.id/index.php/JOE

Research into inflammatory factors as a cause of endometriosis is growing. The inflammatory markers can be examined locally or systemically. One important marker is Interleukin-6 (IL-6) which plays a role in the growth and maintenance of ectopic endometrial tissue. These cytokines act as activating macrophages that can stimulate endometrial cell proliferation and can modulate the secretion of other cytokines such as IL-10, IL-13 and TNF$\alpha$ to further amplify the inflammatory process. High levels of IL-6 in the peritoneum are associated with advanced endometriosis associated with severe pelvic adhesions and embryotoxic effects leading to infertility.

Chronic inflammatory process in endometriosis is associated with the most common symptoms complained such as pain, adhesions of organs and infertility. Complaints of pain occur due to the presence of nerve fibers and Nerves Growth Factor (NGF) produced by endometriosis tissue, direct implantation of endometriosis into the nerves and the estradiol that is converted into prostaglandins which increase the density of nociceptors and modulate pain. ${ }^{11}$ Adhesion is a complex process influenced by many factors. One of them is local inflammation. The occurrence of adhesion and inflammation affects the incidence of infertility. Currently, the Endometriosis Fertility Index (EFI) score is used as an indicator to predict pregnancy in patients undergoing surgery by combining patient history (historical factors) and intraoperative findings (surgical factors). ${ }^{9-13}$

From the description above, the main problem in endometriosis is a chronic inflammatory process which involves several systemic and local inflammatory cytokines. Endometriotic lesions produce inflammatory cytokines, increasing their levels in the peritoneal fluid. This process disrupt the pelvic anatomy, ovarian function, prostaglandin production and production of growth factor that causes pain, adhesions and infertility in endometriosis patients. One of the potential cytokines involved is IL-6. In this study, we will assess the level of IL-6 from peritoneal lavage of patients with endometriosis and analyze the relation of degree of pain, adhesions and EFI scores.

\section{METHODS}

This research is quantitative analytic with cross sectional study design conducted on 22 subjects with endometriosis. Prior to the laparoscopy, a historical factor (EFI score) was done and the degree of pain was carried out by filling out a questionnaire. Intraoperatively, a peritoneal lavage is done if 3-5 cc peritoneal fluid can be taken directly with a $10 \mathrm{cc}$ syringe. If there is no peritoneal, wash the peritoneum using $0.9 \% \mathrm{NaCl}$ and take $3-5 \mathrm{cc}$ from the $0.9 \% \mathrm{NaCl}$ using $10 \mathrm{cc}$ syringe and followed by an examination using the RayBio Human IL-6 ELISA Kit. During a laparoscopic procedure, the degree of adhesion between pelvic organs is assessed by looking at their shape and how the adhesions can be separated. Surgical factor (EFI score) was assessed intraoperatively to obtain data for the least function 


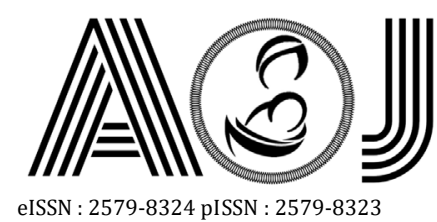

eISSN : 2579-8324 pISSN : 2579-8323
ANDALAS OBSTETRICS AND GYNECOLOGY JOURNAL

Address for Correspondence:

Editorial RoomAndalas Obstetrics and Gynecology Journal, $3^{\text {rd }}$ floorof KSM of Obstetrics and Gynecology,

RSUP DR. M. Djamil Padang, Jl. Perintis Kemerdekaan Padang, Sumatera Barat 25127

Website:

http://jurnalobgin.fk.unand.ac.id/index.php/JOE

score, AFS endometriosis score and AFS total score. Statistical analysis to assess meaning using paired $t$ test and correlation test.

Before this research began, an ethical clearance was submitted to the Research Ethics Commission Team of the Faculty of Medicine, Andalas University, and had received an ethical clearance statement number 290 / KEP / FK / 2020.

\section{RESULTS}

\section{Data's Normality}

The normality test is carried out using the Shapiro Wilk test to determine whether the data is normally distributed or not. The results of the data normality test can be seen in Table 1 below:

Table 1. Data Normality Test

\begin{tabular}{lccc}
\hline \multicolumn{1}{c}{ Variable } & $\mathbf{N}$ & Mean \pm SD & p value \\
\hline $\begin{array}{l}\text { IL-6 level of peritoneal lavage } \\
(\mathrm{pg} / \mathrm{ml})\end{array}$ & 22 & $30.75 \pm 7.01$ & 0.132 \\
EFI Score & 22 & $4.09 \pm 2.09$ & 0.037 \\
\hline
\end{tabular}

Based on Table 1, it is known that the results of the normality test for IL-6 level variable were normally distributed ( $p>0.05$ ) while the EFI score was not normally distributed $(p<0.05)$. Therefore, it is necessary to transform data on the EFI score. After the data transformation was carried out, the following results were obtained:

Table 2. Transformation Data's Normality

\begin{tabular}{|c|c|c|c|}
\hline Variable & $\mathbf{N}$ & Mean \pm SD & p value \\
\hline EFI Score & 22 & $4.09 \pm 2.09$ & 0.007 \\
\hline
\end{tabular}

After transforming the data (table 2), the distribution of the EFI score is still not normal. Therefore, the correlation test used is the Spearman correlation test.

\section{Characteristics of Research Respondents}

The characteristics of the research respondents consisted of age, parity, marital status, infertility and a history of prior pregnancy which can be seen in table 3 . 


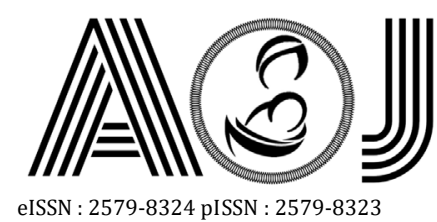

ANDALAS OBSTETRICS AND GYNECOLOGY JOURNAL

Address for Correspondence:

Editorial RoomAndalas Obstetrics and Gynecology Journal, $3^{\text {rd }}$ floorof KSM of Obstetrics and Gynecology,

RSUP DR. M. Djamil Padang, Jl. Perintis Kemerdekaan Padang, Sumatera Barat 25127

Website:

http://jurnalobgin.fk.unand.ac.id/index.php/JOE

Table 3. Characteristics of Respondents

\begin{tabular}{lc}
\hline \multicolumn{1}{c}{ Characteristics } & Mean \pm SD \\
\hline Age (years) & $\mathbf{f ( \% )}$ \\
Parity & $34.86 \pm 6.11$ \\
- Nulliparous & \\
- Multiparous & $18(81.8)$ \\
Marital status & $4(18.2)$ \\
- Married & \\
Infertility & $22(100)$ \\
- Yes & $22(100)$ \\
History of Prior Pregnancy & \\
- No & $18(81.8)$ \\
- Yes & $4(18.2)$ \\
\hline
\end{tabular}

From the table 3 , it is known that the mean age of the respondents is $34.86 \pm 6.11$ years. More than half of the respondents, namely 18 respondents $(81.8 \%)$ are nulliparous. All respondents (100\%) were married. All respondents (100\%) experienced both primary and secondary infertility. Most of the respondents, namely 18 respondents (81.8\%) had no history of prior pregnancy.

3. The relation between IL-6 levels of peritoneal lavage and the degree of pain in endometriosis patients

The relationship between IL-6 levels of peritoneal lavage with the degree of pain can be seen in Table 4 below:

Table 4. Relationship between IL-6 levels of peritoneal lavage and the degree of pain

\begin{tabular}{lccc}
\hline \multicolumn{1}{c}{ Variable } & Severe & Moderate & \\
\cline { 2 - 3 } & $\begin{array}{c}\text { Mean } \pm \text { SD } \\
(\mathrm{pg} / \mathrm{ml})\end{array}$ & $\begin{array}{c}\text { Mean } \pm \text { SD } \\
(\mathrm{pg} / \mathrm{ml})\end{array}$ & p-value \\
\hline $\begin{array}{l}\text { IL-6 level of peritoneal } \\
\text { lavage }(\mathrm{pg} / \mathrm{ml})\end{array}$ & $32.58 \pm 7.31$ & $25.86 \pm 2.62$ & 0.042 \\
\hline
\end{tabular}

From table 4, it is known that the mean levels of IL-6 peritoneal lavage in respondents with a severe degree of pain were higher than those with moderate pain degrees with a result of $32.58 \pm 7.31 \mathrm{pg} / \mathrm{ml}$ and $25.86 \pm 2.62 \mathrm{pg} / \mathrm{ml}$. The results of statistical tests showed that there was a statistically significant relationship between IL- 6 levels of peritoneal lavage with the degree of pain $(p<0.05)$. In this study, there were no respondents with mild degree of pain. 


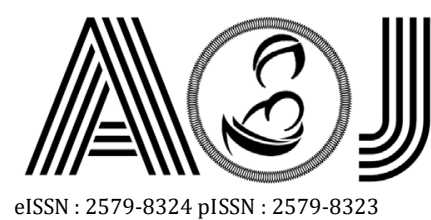

eISSN : 2579-8324 pISSN : 2579-8323
ANDALAS OBSTETRICS AND GYNECOLOGY JOURNAL

Address for Correspondence:

Editorial RoomAndalas Obstetrics and Gynecology Journal, $3^{\text {rd }}$ floorof KSM of Obstetrics and Gynecology,

RSUP DR. M. Djamil Padang, Jl. Perintis Kemerdekaan Padang, Sumatera Barat 25127

Website:

http://jurnalobgin.fk.unand.ac.id/index.php/JOE

\section{The Relation between IL- 6 levels of peritoneal lavage and the degree of adhesions in endometriosis sufferers}

The relationship between IL- 6 levels of peritoneal lavage with the degree of adhesions can be seen in Table 5 below:

Table 5. The relation between IL-6 levels of peritoneal lavage and the degree of adhesions

\begin{tabular}{lccc}
\hline \multicolumn{1}{c}{ Variable } & $\mathbf{3}^{\text {rd }}$ Degree & $\mathbf{2}^{\text {nd }}$ Degree & p-value \\
\cline { 2 - 3 } & $\begin{array}{c}\text { Mean } \pm \text { SD } \\
(\mathbf{p g} / \mathbf{m l})\end{array}$ & $\begin{array}{c}\text { Mean } \pm \text { SD } \\
(\mathbf{p g} / \mathbf{m l})\end{array}$ & \\
\hline $\begin{array}{l}\text { IL-6 level of peritoneal } \\
\text { lavage }(\mathrm{pg} / \mathrm{ml})\end{array}$ & $32.78 \pm 6.65$ & $23.86 \pm 2.18$ & 0.009 \\
\hline
\end{tabular}

Based on Table 5, it is known that the mean levels of IL-6 peritoneal lavage in respondents with third degree adhesion were higher than respondents with second degree adhesion with the results of $32.78 \pm 6.65 \mathrm{pg} / \mathrm{ml}$ and $23.86 \pm 2.18 \mathrm{pg} / \mathrm{ml}$. The relation of the level of IL- 6 in peritoneal lavage with the degree of adhesions is statistically significant ( $p$ $<0.05)$. In this study, there were no respondents with zero and first-degree adhesion.

\section{The correlation between IL-6 level of peritoneal lavage with EFI scores in patients with endometriosis}

The correlation between IL- 6 level in peritoneal lavage with EFI scores in endometriosis patients can be seen in Table 6 below:

Table 6. The correlation between IL-6 Level of Peritoneal Lavage and EFI Score

\begin{tabular}{lccc}
\hline \multicolumn{1}{c}{ Variabel } & Mean \pm SD & R & p-value \\
\hline Level of IL-6 $(\mathrm{pg} / \mathrm{ml})$ & $30.75 \pm 7.01$ & -0.448 & 0.036 \\
Skor EFI & $4.09 \pm 2.09$ & & \\
\hline
\end{tabular}

Based on Table 6, it can be concluded that the mean level of IL-6 was $30.75 \pm 7.01$ $\mathrm{pg} / \mathrm{ml}$ and an the mean EFI score was $4.09 \pm 2.09$. The correlation of IL-6 levels in peritoneal lavage with EFI score showed a value of $r=-0.448$ which had moderate strength and a negative pattern, meaning the higher the IL-6 level of peritoneal lavage will show lower the EFI score. The analysis showed that there was a relationship between IL-6 levels in peritoneal lavage and the EFI score in patients with endometriosis cysts $(p<0.05)$.

The prediction of the correlation of IL-6 peritoneal rinse with the EFI score can be seen in Figure 1 below: 


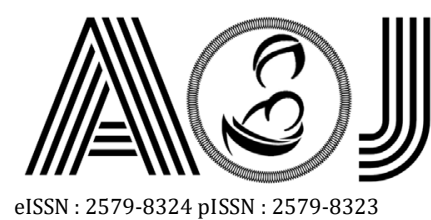

eISSN : 2579-8324 pISSN : 2579-8323

ANDALAS OBSTETRICS AND GYNECOLOGY JOURNAL

Address for Correspondence:

Editorial RoomAndalas Obstetrics and Gynecology Journal, $3^{\text {rd }}$ floorof KSM of Obstetrics and Gynecology, RSUP DR. M. Djamil Padang, Jl. Perintis Kemerdekaan Padang, Sumatera Barat 25127

http://jurnalobgin.fk.unand.ac.id/index.php/JOE

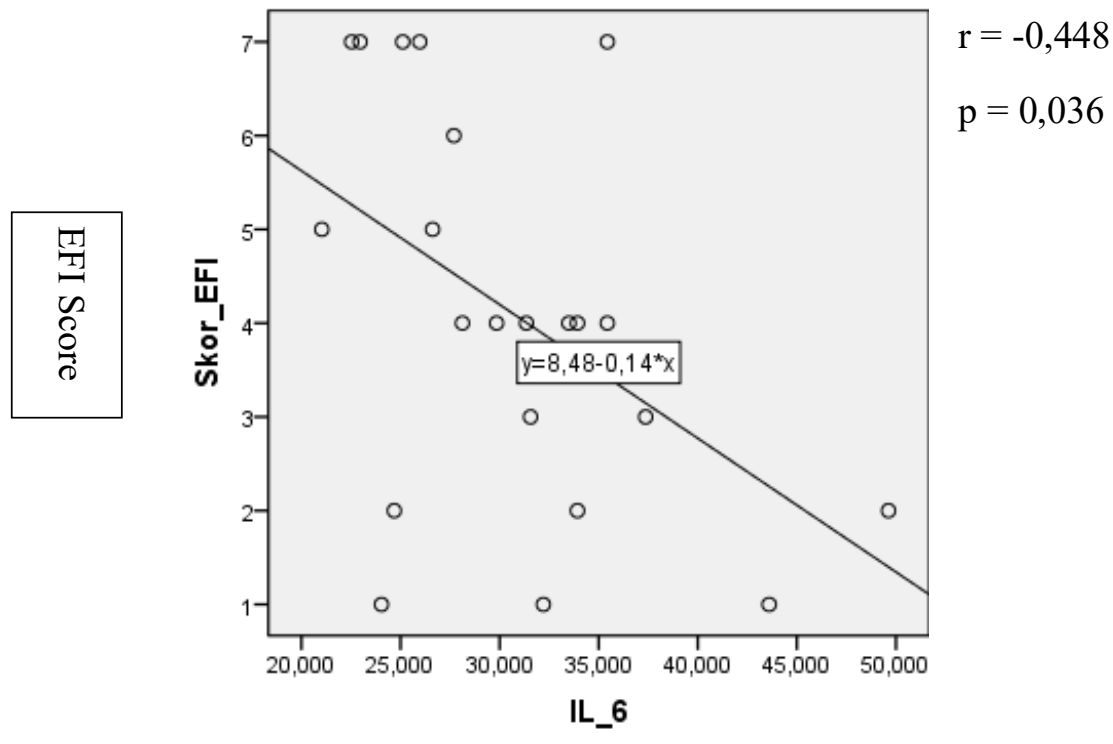

Figure 1. The Correlation Between IL-6 Peritoneal Lavage and EFI Score

\section{DISCUSSION}

\section{The correlation between IL-6 Levels of Peritoneal Lavage with the Degree of Pain in Endometriosis Patients}

Based on the results found, it is known that the mean levels of IL- 6 of peritoneal lavagein respondents with a severe degree of pain were higher than those with moderate pain degrees with the results respectively $32.58 \pm 7.31 \mathrm{pg} / \mathrm{ml}$ and $25.86 \pm 2.62 \mathrm{pg} / \mathrm{ml}$. There were no respondents with mild pain. The analysis showed that there was a relationship between IL-6 levels of peritoneal lavage with the degree of pain.

The results of this study are in line with that conducted by Ashraf et al (2012) that had also founda correlation between IL-6 concentrations in peritoneal fluid and the degree of pain in endometriosis patients. In a study conducted on 95 women, which were divided into 30 controlgroups and 65 subjects with endometriosis divided tothe degree of pain severity, mild to moderate and severe pain. It was found that IL- 6 and TNF- $\alpha$ found in serum and peritoneal fluid had significantly increased in patients with endometriosis compared to controls $(P<0.001)$. IL-6 levels in peritoneal fluid increased significantly in patients with pain $(59.94 \pm 10.29 \mathrm{pg} / \mathrm{ml}$ and $47.12 \pm 6.02 \mathrm{pg} / \mathrm{ml})$ compared to controls $(14.42 \pm 5.47 \mathrm{pg} / \mathrm{ml})$. In this study, the examination was carried out using blood samples taken from patients during 


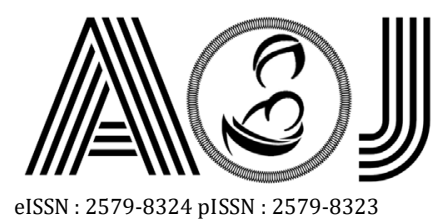

eISSN : 2579-8324 pISSN : 2579-8323

fasting and follicular phase (day 5-10) and peritoneal fluid samples were taken from the douglas cavity during laparoscopy. ${ }^{1,15}$

Research by Rapkin et al (2000) also showed similar result where they also found an increase ofthe mean IL-6 level found in the peritoneal fluid from patients with endometriosis with pelvic pain $(15.34 \pm 50.56 \mathrm{pg} / \mathrm{mL})$ compared to patients without pelvic pain $(5.19 \pm 9.74 \mathrm{pg} / \mathrm{mL})$. Although the difference between IL- 6 levels between groups were quite high, there was no statistically significant difference found in this study. The occurrence of pelvic pain in patients with endometriosis is not only due to the presence of inflammatory cytokines in the peritoneal fluid, but also involves complex processes both peripherally and centrally. ${ }^{16}$

Endometriosis is a disorder caused by an inflammatory process that causes an increase in the amount of peritoneal fluid and involves cytokines, one of them is IL-6. Patients with endometriosis have seen an increase in peritoneal fluid IL-6 which plays a role in the pathogenesis of endometriosis by initiating and maintaining an inflammatory response. The IL- 6 assay has been used to differentiate women with or without endometriosis and to identify the degree of endometriosis. In early-grade endometriosis with more active lesions, it was found that cytokine secretion is increased. This explains the pain experienced is not related to the degree of disease. ${ }^{1,17}$

\section{Relationship between IL- 6 levels of peritoneal Lavage with the degree of adhesions in} endometriosis Patients

Based on the results of the study, it is known that the mean levels of IL-6 peritoneal lavagein respondents with third degree adhesion were higher than second degree adhesion with the results of $32.78 \pm 6.65 \mathrm{pg} / \mathrm{ml}$ and $23.86 \pm 2.18 \mathrm{pg} / \mathrm{ml}$. There were no respondents with zero and first-degree adhesion. The analysis showed that there was a correlation between IL-6 levels in peritoneal lavageand the degree of adhesions.

IL-6 level in peritoneal lavage are frequently elevated in women with pelvic malignancies such as ovarian carcinoma, but are also reported to increased in patients with pelvic adhesions and endometriosis. Several studies have shown increased IL-6 levels in 
peritoneal lavage of patients with pelvic adhesions and endometriosis. The results of a study conducted by Rapkin et al (2000) showed that mean IL-6 levels in patients with pelvic adhesions were $16.35 \pm 51.17 \mathrm{pg} / \mathrm{mL}$. At this level, pelvic adhesions are accompanied by complaints of pain. ${ }^{16}$

The results of this study are in line with the research conducted by Cheong et al (2002) which showed that the mean IL-6 concentration of peritoneal fluid in women with pelvic adhesions was $41 \pm 7.5 \mathrm{pg} / \mathrm{ml}$, higher compared to women with normal pelvic conditions with mean IL-6 levels of $27.9 \pm 4.2 \mathrm{pg} / \mathrm{ml}$. This study also assessed the effect of inflammatory cytokines on the degree of adhesion. The results showed that the mean IL-6 levels of peritoneal lavage in women with mild, moderate and severe adhesions were 27.5 $\pm 2.6 \mathrm{pg} / \mathrm{ml}, 51 \pm 4 \mathrm{pg} / \mathrm{ml}$, and $77.8 \pm 8 \mathrm{pg} / \mathrm{ml}$. Therefore higher IL-6 level found in the peritoneal fluid correlate with heavier the degree of organ adhesion, yet there is no statistically significant difference. ${ }^{18}$

A study by Barcz et al (2012) showed similar result as they also found that IL-6 level in peritoneal fluid was statistically higher in patients with adhesion than without adhesion. The mean IL-6 levels of peritoneal fluid in endometriosis patients with pelvic adhesions was $37.7 \pm 19.7-124.9 \mathrm{pg} / \mathrm{ml}$, whereas in women with endometriosis without pelvic adhesions was $25.2 \pm 15.8-34.4 \mathrm{pg} / \mathrm{ml}$. This study also showed a correlation between IL-6 levels in the peritoneal fluid with pelvic adhesion score with a value of $r=0.4$ which has moderate strength and a positive pattern, hence higher the IL- 6 level of peritoneal lavage is found in higher the degree of adhesion. The analysis showed that there was a statistically significant relation between IL- 6 levels in peritoneal lavage and the degree of adhesion in patients with endometriosis cysts $(p=0.002) .{ }^{19}$ Buyalos et al (1992) also found that IL-6 levels of peritoneal fluid were found to be elevated in patients with pelvic adhesions $(1.28 \pm 0.16$ $\mathrm{ng} / \mathrm{ml})$ versus controls $(0.80 \pm 0.06 \mathrm{ng} / \mathrm{ml})$ with $\mathrm{P}<0.03 .{ }^{20}$

Endometriosis is one of the main causes of pelvic adhesionwithout a previous history of surgery. Pelvic adhesion can occur due to three important components, namely the inflammatory process, fibrinolysis disorders and the protease / protease inhibitor system. Important proinflammatory cytokines involved in adhesion are IL-1, IL-6 and TNF- $\alpha$. These 


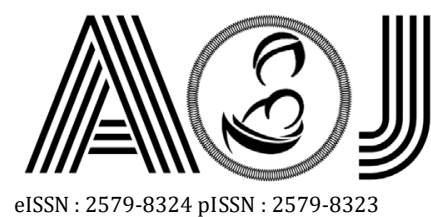

eISSN : 2579-8324 pISSN : 2579-8323
ANDALAS OBSTETRICS AND GYNECOLOGY JOURNAL

Address for Correspondence:

Editorial RoomAndalas Obstetrics and Gynecology Journal, $3^{\text {rd }}$ floorof KSM of Obstetrics and Gynecology, RSUP DR. M. Djamil Padang, Jl. Perintis Kemerdekaan Padang, Sumatera Barat 25127

Website:

http://jurnalobgin.fk.unand.ac.id/index.php/JOE

cytokines are found to be increased in peritoneal fluid of patients with endometriosis due to active endometriosis which involves an inflammatory process. These cytokines cause adhesion by inhibiting fibrinolysis through activation of plasminogen activator inhibitor-1 (PAI-1). Endometriosis-related adhesions have different types, they can be thin, filmy and transparent or thick, solid and opaque. In severe cases, the adhesions can cause frozen pelvis. El Kader et al (2019) found $37.6 \%$ cases of adhesions in endometriosis patient who underwent laparoscopy and the most common adhesions found were adnexal adhesions (51.2\%) with moderate adhesions (46.3\%). The presence of adhesions affects the patient's quality of life $(P=0.002)$ and is associated with infertility, chronic pelvic pain and intestinal obstruction. ${ }^{19,21}$

\section{Correlation of IL-6 levels in peritoneal swabs with EFI scores in patients with endometriosis}

Based on the results of the study, it was found that the higher the IL-6 level of peritoneal rinse, the lower the Endometriosis Fertility Index (EFI) score with the Spearman correlation showing the value of $r=-0.448$ which had moderate strength and had a negative pattern. Increased levels of IL-6 in peritoneal lavage reflect local inflammatory processes, decreasing the rate of pregnancy. Therefore, inflammation is a crucial factor that makes it difficult for endometriosis patients to conceive. The analysis showed that there was a correlation between IL-6 levels in peritoneal lavage and the EFI score.

The results of the study by Wang et al (2018) found that the IL-6 levels of peritoneal fluid in endometriosis patients with infertility increased significantly compared to controls ( $P$ $<0.05)$. The mean IL-6 levels in peritoneal fluid of endometriosis patients with infertility were $48.15 \pm 9.83 \mathrm{pg} / \mathrm{ml}$, while those in controls were $18.14 \pm 9.03 \mathrm{pg} / \mathrm{ml}$. This study also found a significant correlation between inflammatory factors (IL-1, IL-6, IL-13 and TNF- $\alpha$ ) in the peritoneal fluid and the occurrence of infertility $(P<0.05){ }^{22}$

Harada et al (2001) stated that IL-6 levels in peritoneal fluid of patients with endometriosis were higher than in patients without endometriosis. IL-6 is thought to have an adverse effect by reducing fecundity in the reproductive process. The increase of this 


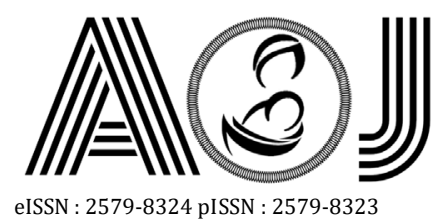

eISSN : 2579-8324 pISSN : 2579-8323
ANDALAS OBSTETRICS AND GYNECOLOGY JOURNAL

Address for Correspondence:

Editorial RoomAndalas Obstetrics and Gynecology Journal, $3^{\text {rd }}$ floorof KSM of Obstetrics and Gynecology, RSUP DR. M. Djamil Padang, Jl. Perintis Kemerdekaan Padang, Sumatera Barat 25127

http://jurnalobgin.fk.unand.ac.id/index.php/JOE

cytokine levels correlates with the amount of active red peritoneal endometriosis associated with infertility. The study also stated that the pregnancy rate after treatment for endometriosis based on the r-AFS classification (American Fertility Society Classifications) was $38 \%$ for $1^{\text {st }}$ degree, $30 \%$ for $2^{\text {nd }}$ degree, $35 \%$ for $3^{\text {rd }}$ degree and $32 \%$ for $4^{\text {th }}$ degree..$^{23}$

Hadisaputra (2013) in his study found that the most common complaints from endometriosis patients studied were infertility (77.8\%). The results of this study also found that infertility was correlated with endometriosis where the odds ratio of the occurrence of infertility was 134.3. In the bivariate analysis, there was a statistically significant relation between the mean levels of IL- 6 and TNF- $\alpha$ with the incidence of infertility $(P<0.05)$. There are several theories that can help to explain the relationship between infertility and endometriosis is the number of peritoneal macrophages that can phagocyte spermatozoa, increasedconcentration of peritoneal cytokines that can interfere with ovulation, and the emergence of anti-alanin autoantibodies that play a role in failure of implantation. ${ }^{24}$

Endometriosis is a complex inflammatory disease that can cause infertility. The rate of fecundity or the possibility of getting pregnant every month in women with endometriosis is $2-10 \%$, lower compared to normal (15-20\%). Apart from anatomical factors, adhesions, oocyte quality factors, sperm factors and ovarian reserve factors, inflammatory factors in endometriosis also affect a woman's chances of becoming pregnant. In endometriosis there is an increase in the accumulation of peritoneal fluid accompanied by an increase in activated macrophages, lymphocytes and prostaglandins. Peritoneal environmental conditions that are abnormal in terms of composition and number, accompanied by chronic inflammation, cause fertility problems through disruption of adhesion, distortion of pelvic organs, disturbance of folliculogenesis, sperm motility, oocyte and uterotubal disorders. In women with endometriosis, IL-6 is also found to be elevated in antral follicular fluid, interfering with folliculogenesis and egg quality associated with infertility. ${ }^{6,14,25,26}$

Currently, the system used to determine the classification of the degree of endometriosis is r-AFS. However, this system cannot predict the outcome of treatment effectively, especially in relation to the pregnancy rate in infertile women. Therefore, in 


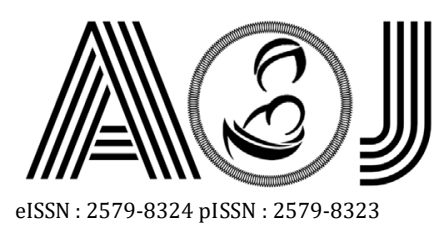

eISSN : 2579-8324 pISSN : 2579-8323

2010 Adamson and Pasta proposed the Endometriosis Fertility Index (EFI) as a new scoring system that combines historical factors (age, duration of infertility and previous pregnancy history) and surgical factors (LF score, AFS endometriosis score and AFS total score). Higher the EFI score means higher the chance for spontaneousconception. ${ }^{27}$ Li Xin et al (2017) found that the mean EFI score from 345 patients with endometriosis was $6.5 \pm 1.9$ and the highest score was 7. From this study, it was found that the possibility of spontaneous conception after surgery was $46.5 \%$, lower than those who underwent the IVF program, which is $54.6 \% .^{28}$

\section{CONCLUSION}

There was a positive correlation between the IL- 6 levels of peritoneal lavage with the degree of pain and adhesion and there was a negative correlation between the IL-6 levels of peritoneal rinses and the EFI score, where higher the IL-6 levels of peritoneal lavage is often found in patients with lower the EFI score.

\section{REFERENCE}

1. Himpunan Endokrinologi Reproduksi dan Fertilitas - Persatuan Obstetri dan Ginekologi Indonesia. Konsensus Tatalaksana Nyeri Haid pada Endometriosis. 2013.

2. Harada, T, Taniguchi F, Onishi,K et al. Obstetrical Complications in Women with Endometriosis: A Cohort Study in Japan. Research articcle. 2016.

3. Brosens, I, Puttemans, P, Benagiano, G. Reproductive Endocrinology and Infertility Endometriosis: A Life Cycle Approach?. American Journal Obstetrics and Gynecology. 2013.

4. Petraglia, S, Arcuri, F, Zigler, D.D, Chapron, C. Inflammation : A Link between Endometriosis and Preterm Birth. France. 2012.

5. Ahn, S.H, Singh, V, Tayade, C. Biomarkers in Endometriosis : Challenges and Opportunities. Department of Biomedical and Molecular Science Queen's University Canada. 2017. 
6. Miller, J.E, Ahn, S.H, Monsanto, S.P, Khalaj, K, Koti, M. Tayede, C. Implications of Immune Dysfunction on Endometriosis Associated Infertility. Department of Biomedical and Molecular Science Queen's University Canada. 2016. Oncotarget 8 (4) : 7138 7147.

7. Elnouri, A. Endometriosis at Invited speaker abstracts from the 24th EBCOG European Congress of Obstetrics and Gynaecology held in Torino Italy. Cairo University : 251-263. 2016.

8. Morassutto, C, Monasta, L, Ricci, G, Barbonr, F, Ronfani, L. Incidence and Estimated Prevalence of Endometriosis and Adenomyosis in Northeast Italy: A Data Linkage Study. 2016.

9. Wu, I.B, Tendean, H.M, Mewengkang, M.E. Gambaran Karakteristik Penderita Endometriosis di RSUP Prof. Dr. R. D. Kandou Manado. Bagian Obstetri dan Ginekologi Fakultas Kedokteran Unsrat. 2017.

10. Suparman, E. Penatalaksanaan Endometriosis. Bagian/SMF Obsteri dan Ginekologi Fakultas Kedokteran Universitas Samratulangi. 2012.

11. Sakti, I.R, Hardianto, G. Dismenore pada Pasien Endometriosis yang Menjalani Laparoskopi. Program Studi Pendidikan Bidan Fakultas Kedokteran Universitas Airlangga. 2013.

12. Hendry, D, Hidayat, A. Karakteristik Penderita Endometriosis dan Adenomiosis di RSUP DR M Djamil Padang Periode Januari 2017-Oktober 2018. Andalas Obstetrics dan Gynecology Journal. 2019.

13. Wu, M.H, Hsiao, K.Y, Tsai, S.J. Endometriosis and Possible Inflammation Markers on Gynecology and minimally Invasive Therapy. 2015.

14. Tanbo, T. Endometriosis-associated Infertility: Aspects of Pathophysiological Mechanisms and Treatment Options. Acta Obstet Gynecol Scand. 96: 659-667. 2016.

15. Ashraf A, Ibrahim A. Role of some biomarkers in chronic pelvic pain for early detection of endometriosis in infertile women. Fertility and Sterility. 2012.

16. Rapkin A, Morgan M, Bonpane C, Maza OM. Peritoneal fluid interleukin-6 in women with chronic pelvic pain. Fertility and Sterility. 2000;74(2):325-8. 
17. Andrade VTD, Nacul AP, Santos BRD, Lecke SB, Spritzer PM. Circulating and peritoneal fluid interleukin-6 levels and gene expression in pelvic endometriosis. Experimental and Therapeutic Medicine. 2017;14:2317-22.

18. Cheong YC, Shelton JB, Laird SM, Richmond, Kudesia G, Li TC, et al. IL-1, IL-6, and TNF-a concentrations in the peritoneal fluid of women with pelvic adhesions. Human Reproduction. 2002;17(1):69-75.

19. Barcz E, Milewski L, Dziunycz P, Kaminski P, P 1oski R, Malejczyk J. Peritoneal cytokines and adhesion formation in endometriosis: an inverse association with VEGF concentration. Fertil Steril 2012. doi: 10.1016/j.fertnstert. 2012.03.057.

20. Buyalos RP, Funari VA, Azziz R, Watson JM, Martinez-Maza O. Elevated interleukin-6 levels in peritoneal fluid of patients with pelvic pathology. Fertil Steril 1992;58:302-6.

21. El Kader, A.I, Gonied, A.S, Mohamed, M.L. Impact of Endometriosis Related Adhesions on Quality of Life among Infertile Women. Royan Institute International Journal of Fertility and Sterility. 2019.

22. Wang, X.M, Ma, Z.Y, Song, N. Inflammatory cytokines IL-6, IL-10, IL-13, TNF- $\alpha$ and peritoneal fluid flora were associated with infertility in patients with endometriosis. European Review for Medical and Pharmacological Sciences. 2018.

23. Iwabe T, Harada T, Terakawa N. Role of Cytokines in Endometriosis-Associated Infertility. Gynecol Obstet Invest. 2002;53(1):19-25.

24. Hadisaputra W. Clinical signs, symptoms and serum level of interleukin-6 and tumor necrosis factor in women with or without endometriosis. Asian Pasific Journal of Reproduction. 2013;2(2):142-5.

25. Lin, Y.H, Chen, Y.H, Chang, H.Y, et al. Chronic Niche Inflammation in Endometriosis-Associated Infertility: Current Understanding and Future Therapeutic Strategies. International Journal of Molecular Sciences. 2018.

26. Wahyuni, A. Endometriosis dan Infertilitas. Bagian Ilmu Obstetri dan Ginekologi Program Studi Pendidikan Dokter Universitas Muhammadiyah Yogyakarta. 2008.

27. Adamson, G.D, Pasta, D.J. Endometriosis Fertility Index: The New, Validated Endometriosis Staging System. American Society for Reproductive Medicine. 2010. 


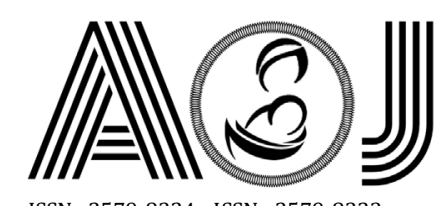

eISSN : 2579-8324 pISSN : 2579-8323

Editorial RoomAndalas Obstetrics and Gynecology Journal, $3^{\text {rd }}$ floorof KSM of Obstetrics and Gynecology, RSUP DR. M. Djamil Padang, Jl. Perintis Kemerdekaan Padang, Sumatera Barat 25127

\section{Website:}

http://jurnalobgin.fk.unand.ac.id/index.php/JOE

28. Li, X, Zheng, C, Zhao, YF et al. Endometriosis Fertility Index for Predicting Pregnancy After Endometriosis Surgery. Chinese Medical Journal. 2017;130(16). 